\title{
Methane Fermentation of Night Soil and Food Waste Mixture
}

\author{
Assadawut Khanto and Peerakarn Banjerdkij
}

\begin{abstract}
Ranges of environmental problem from human activities have become a global problem. Therefore, reducing volume of waste such as a nigh soil and food wastes to use as resource materials were considered. The anaerobic batch reactor experiments were conducted to investigate the COD removal and biogas production from night soil and night soil with additional $10 \%$ food waste. The 4 batch reactors experiment were conducted, night soil were contained as a fermentation materials for reactor 1-3 and for reactor 4 the night soil with additional $10 \%$ food waste were investigated to compare. The experiments were operated at room temperature varies from $25-37^{\circ} \mathrm{C}$ within 3 months experiment. The results show $90 \%$ COD removal and about $50 \%$ methane production occurred in this experiment. STKN and sTP have also investigated in this experiment. STKN concentration remain constant during experiment period and slightly increase of sTP concentration were appeared.
\end{abstract}

Index Terms-Anaerobic condition, anaerobic batch reactor, biogas production, fermentation.

\section{INTRODUCTION}

Nowadays a range of environmental problem from human economic activities such as transportation, emission from industry and other activities have become apparent. The most notable of these problems are global warming due to greenhouse gas and other emission.

From the mention above, therefore, increasing of strong demand for reducing the volume of waste material such as nigh soil and food waste, effectively using these waste materials as a resource, and processing or treatment them appropriately.

Therefore, newly design of anaerobic tank has been designed to treat the night soil and food waste from building, condominium and any department store. The biogas was obtained to be used as the advantage such as renewable energy to produce electricity, heat return to the building to reduce operation cost. Within this context, Environmental Engineering (Kasetsart University, Bangkok) was conducted the anaerobic batch reactor experiments to investigate the biogas production from pure night soil and night soil with $10 \%$ (by volume of reactor) additional food waste for increasing organic loading which would be observed to compared the results of biogas production.

This current work presents the results of investigated parameters over 3 months for anaerobic batch reactors

Manuscript received December 26, 2012; revised January 23, 2013.

Assadawut Khanto is with Department of Environmental Engineering, Faculty of Engineer, Kasetsart University, Thailand (e-mail: assadawut.k@hotmail.com).

Peerakarn Banjerdkij is with Faculty of Engineer, Kasetsart University, Thailand. experiment.

\section{METHOD}

\section{A. Characterization of Night Soil and Food Waste.}

The night soil was collected from Nong Khaem wastewater treatment located at Bangkok Province. Night soils were collected after screen drum process before released to treat at activated sludge process. The food wastes were obtained

from faculty of science canteen (Kasetsart University) and have been compacted before released to the reactor.

\section{B. Anaerobic Reactor}

Experiments were carried out in a $20 \mathrm{~L}$ batch-type reactor and were operated at a room temperature vary from $25-37^{\circ} \mathrm{C}$ throughout the experiment. Fig. 1 illustrates the experiment set-up. The reactors were divided into 3 sections which were free board (on top), fermentation section in the middle of reactor and sedimentation section, respectively. The anaerobic batch reactors were equipped with three parts at the top, one for feeding the night soil and food waste, and another for biogas collection and on beside of reactor, there were sampling port where samples have been taken to observe.

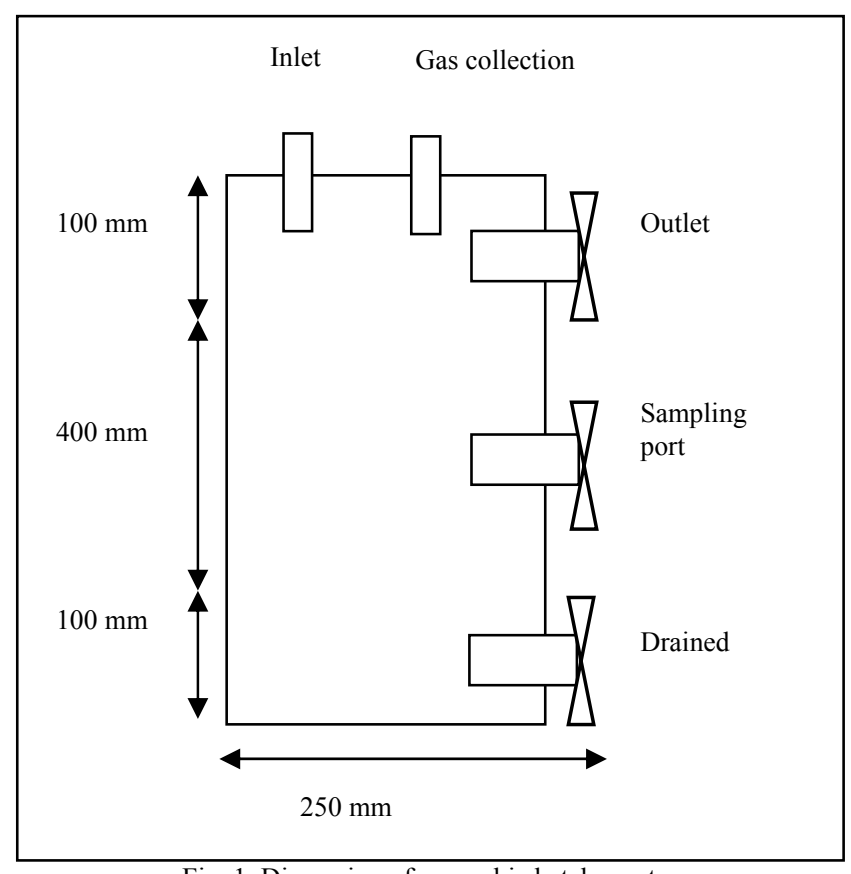

Fig. 1. Dimension of anaerobic batch reactor

Fig. 2. shows the anaerobic batch reactor. The amounts of night soil and night soil with $10 \%$ by volume of food waste introduced to the reactors were in total $20 \mathrm{~L}$ as indicated in the condition Table I. 


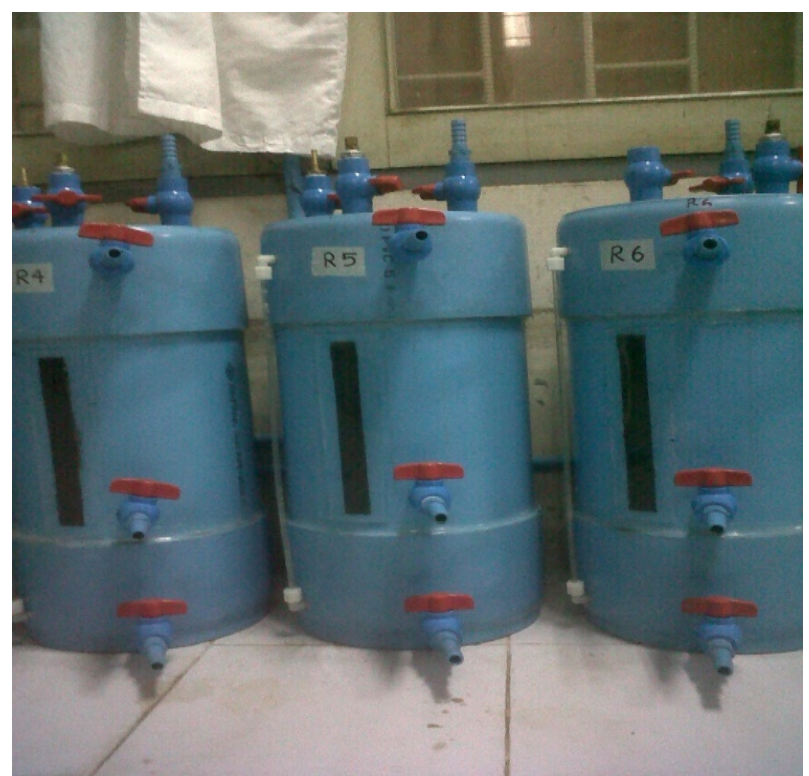

Fig. 2. Anaerobic batch reactor

TABLE I: TEST CONDITIONS

\begin{tabular}{ccc}
\hline Item & $\begin{array}{c}\text { Fermentation material } \\
\text { (litters) }\end{array}$ & Additional food waste (liters) \\
\hline Run1 & 20 & - \\
Run2 & 20 & - \\
Run3 & 20 & - \\
Run4 & 18 & 2 \\
\hline
\end{tabular}

The various process employed area outlined below.

1) The night soil taken from Nong Khaem wastewater treatment and compacted food waste has been taken to batch reactor by release into the inlet channel.

2) Fermentation: The microorganisms employed in methane fermentation required accurate control of processing temperature facilitate the fermentation reaction. All fermentation process (Reactor 1-4) employ at room temperature

3) Gas Collection: Gas collecting bag was used to collect the gas production from reactor. Afterward, the methane and others production were results by GC 6890 machine, which $\mathrm{CO}_{2}, \mathrm{CH}_{4}, \mathrm{O}_{2}$ and $\mathrm{N}_{2}$ can be measured.

\section{Analytical Methods}

Table II shows analyze parameters such as $\mathrm{pH}$, sCOD, sTKN, sTP, TS and VS. The laboratory was measured by using Standard method of examination of water and wastewater $22^{\text {th }}$ ed [1] and Analysis water quality $5^{\text {th }}$ [2] Three rectors contained night soil under anaerobic condition will be observed over experiment time.

\begin{tabular}{ll} 
& TABLE II: ANALYZE PARAMETERS \\
\hline Parameters & Methods \\
\hline $\mathrm{pH}$ & $\mathrm{pH}$ Meter \\
sCOD & Closed Reflux Method \\
sTKN & Macro-Kjeldahl Method \\
sTP & Ascorbic Acid Method \\
TS & Oven at 103-105 oC \\
VS & Oven at 550 oC \\
VSS & Filtered and oven at $550 \mathrm{oC}$ \\
\hline
\end{tabular}

Table III shows the characteristic of fermentation material in anaerobic batch reactor. The $\mathrm{pH}$ obtained from reactor 1-3 was in the range of 7.45-7.87 where the proper $\mathrm{pH}$ in anaerobic condition was in the range of 5.5-8 [3] and 6.6-7.6
[4], [5]. Moreover, methane productions with high rate performance were in range of 6.5-7.5 [6] and 7.0-7.2 [7].

TABLE III: CHARACTERIZATION OF NIGHT SOIL

\begin{tabular}{llll}
\hline \multirow{2}{*}{ Items } & Unit & Inlet & Night soil $+10 \% \mathrm{FW}$ \\
\cline { 3 - 4 } & & Night soil & $6.35-7.0$ \\
\hline $\mathrm{pH}$ & - & $7.45-7.87$ & - \\
\hline $\mathrm{BOD}$ & $\mathrm{mg} / 1$ & $2,175-2,450$ & - \\
\hline $\mathrm{sCOD}$ & $\mathrm{mg} / 1$ & $3,104-8,400$ & $37,224-2,034$ \\
\hline $\mathrm{COD}$ & $\mathrm{mg} / 1$ & $4,613-9,118$ & - \\
\hline $\mathrm{sTKN}$ & $\mathrm{mg} / 1$ & $305-308$ & - \\
\hline $\mathrm{sTP}$ & $\mathrm{mg} / 1$ & $1,054-1,842$ & $7,303-49,333$ \\
\hline $\mathrm{TS}$ & $\mathrm{mg} / 1$ & $4,932-22,675$ & $5,013-35,663$ \\
\hline $\mathrm{VS}$ & $\mathrm{mg} / 1$ & $3,210-19,271$ &
\end{tabular}

The $\mathrm{pH}$ of additional $10 \%$ food waste to night soil in reactor 4 experiment were lower due to the characteristic of food wastes were in acid condition, the average $\mathrm{pH}$ of food waste were about 4.5 [8] and in range of 4.5-5.3 [9].The soluble chemical oxygen demand (SCOD) has been measured in this experiment and its range between $3104-8,400 \mathrm{mg} / \mathrm{l}$ and COD concentration were in the range of 4,613-9,118 mg/l which more than average community wastewater where COD in the range of $300-1,000 \mathrm{mg} / \mathrm{l}$ [10] This is according to the treatment by anaerobic condition where COD concentrations suppose to exceed 1,270 mg/l [10] Otherwise, the addition heat for anaerobic reactor will be added into the process for biogas production [10] and will be uneconomically. The $\mathrm{C} / \mathrm{N}$ ratio were in range $10-50$ where the proper $\mathrm{C} / \mathrm{N}$ ratio for biogas production in the range about 20-30 [11]. The additional $10 \%$ food waste to night soil, COD concentration was highly increased 10 times more than reactor 1-3 where purely night soil contained. This is due to additional food waste has high organic compound resulting in higher COD concentration and organic loading in experiment 4 [8]

\section{RESULTS AND DISCUSSION}

Table IV shows the efficiency of anaerobic reactor. The beginning SCOD measurement was 3,104 mg/l and reducing to $1550.93 \mathrm{mg} / 1$ or $50.03 \%$ COD removal within 5 days experiment. However, $84 \%$ COD removal was obtained from swine farm wastewater treatment within 4 days experiments and operated with completer mixed [12]

TABLE IV: EFFICIENCY OF ANAEROBIC REACTOR

\begin{tabular}{lll}
\hline \multirow{2}{*}{ Time(days) } & $\mathrm{sCOD}(\mathrm{mg} / \mathrm{l})$ & Efficiency $(\%)$ \\
\cline { 2 - 3 } & & $\mathrm{sCOD}$ \\
\hline beginning & 3104.00 & - \\
\hline 5 & 1550.98 & 50.03 \\
\hline 10 & 1034.38 & 66.68 \\
\hline 15 & 364.00 & 88.27 \\
\hline 32 & 526.27 & 83.05 \\
\hline 71 & 418.24 & 86.53 \\
\hline 80 & 302.33 & 90.26 \\
\hline 86 & 357 & 86.94 \\
\hline
\end{tabular}

This was indicated that a complete mixed in anaerobic reactor has effected to the degradation by bacteria to an 
organic matter within the anaerobic reactor resulting to the biogas production [6] Afterward, sCOD reducing to 357.00 $\mathrm{mg} / \mathrm{l}$ or $88.27 \%$ after 15 days experiment and remains constant sCOD concentration until the end of experiment, which according to the complete-mix anaerobic digester, the hydraulic retention time are equal to solid retention time and may be in the range of 15-30 days [10]. Fig. 3 shows the amount of SCOD concentration $(\mathrm{mg} / \mathrm{l})$ of reactor 1-3 which nigh soil were contained to experiment show tendency to decreasing over $15^{\text {th }}$ days and remained constant afterward. This is due to the anaerobic treatment process was taken place in this experiment. The $88.27 \%$ efficiency of COD removal was obtained from this experiment. During this run $\mathrm{pH}$ results were fluctuation in first fifteen days. Afterward, $\mathrm{pH}$ was decreasing and remains constant from $74^{\text {th }}$ days to the end of experiment. This is due to the acidogenesis process has taken place result in decreasing of $\mathrm{pH}$ of experiment. The degradation under acidogenesis step where acid forming bacteria produce acetate and others acid substrate. [13] The sTKN concentration were started at $308 \mathrm{mg} / \mathrm{l}$ and remains constant due to sTKN was not treated under anaerobic condition [14]

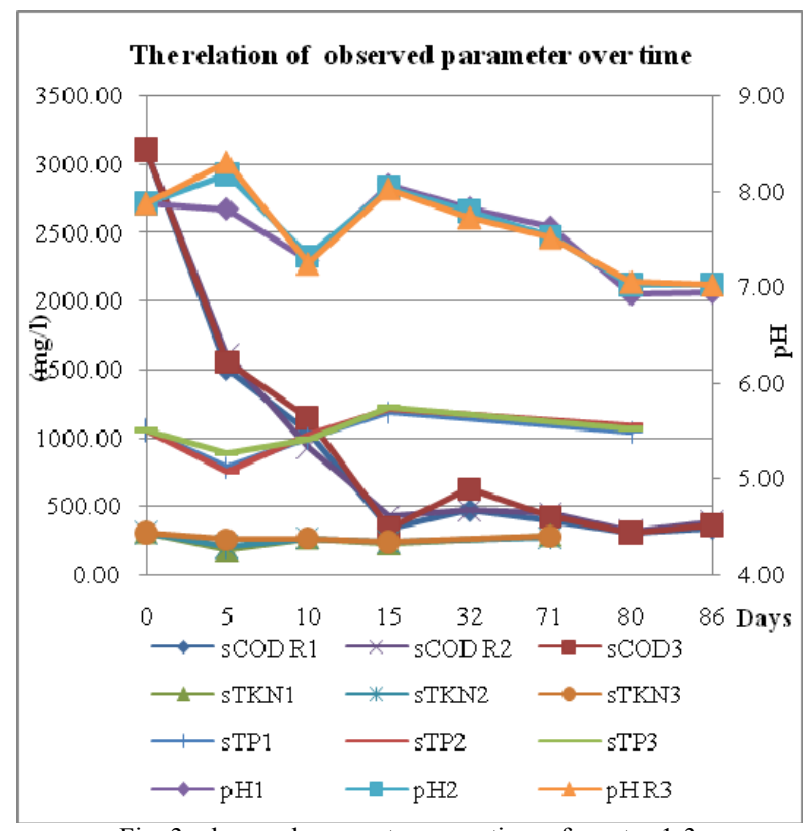

Fig. 3. observed parameters over time of reactor $1-3$

Moreover, sTP concentration were started at 1,054 mg/l and were slightly increase until the end of experiment. This due to under depleted of oxygen acetate were taken into cell of bacterial and orthophosphate were released [10] results in increase of sTP in reactor.

Fig. 4 shows the comparison between COD and $\mathrm{pH}$ over an experiment time. Reactor 1-3 night soils were contained as fermentation material and reactor 4 night soil $+10 \%$ food waste have been investigated. The additional of $10 \%$ food waste, where it has high organic matter, to night soil in reactor 4 result in 10 times COD concentration higher than reactor 1-3. During this run $\mathrm{pH}$ results of reactor 1-3 were fluctuation in range of 7-8 according to $\mathrm{pH}$ investigated from night soil were average at 7.2 [8] The $\mathrm{pH}$ of reactor 4 was in the range of 6.5-6.9 and remains lower than reactor 1-3. These may due to the additional of food waste where $\mathrm{pH}$ contained in acid condition average about 4.5 [8] to the night soil result in drop of $\mathrm{pH}$. However, it were still in the range of proper anaerobic treatment condition $\mathrm{pH}$ in range of 5.5-8 (Clark, R.H et al., 1974) and 6.6-7.6 [6].Moreover, methane production with high rate performance were in range of $6.5-7.5[6]$

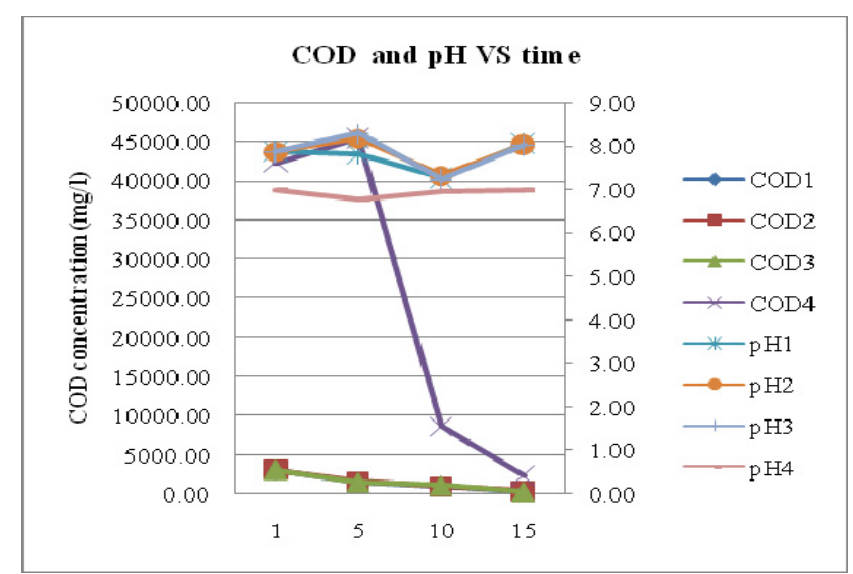

Fig. 4. Comparison of COD and $\mathrm{pH}$ of reactor 1-4

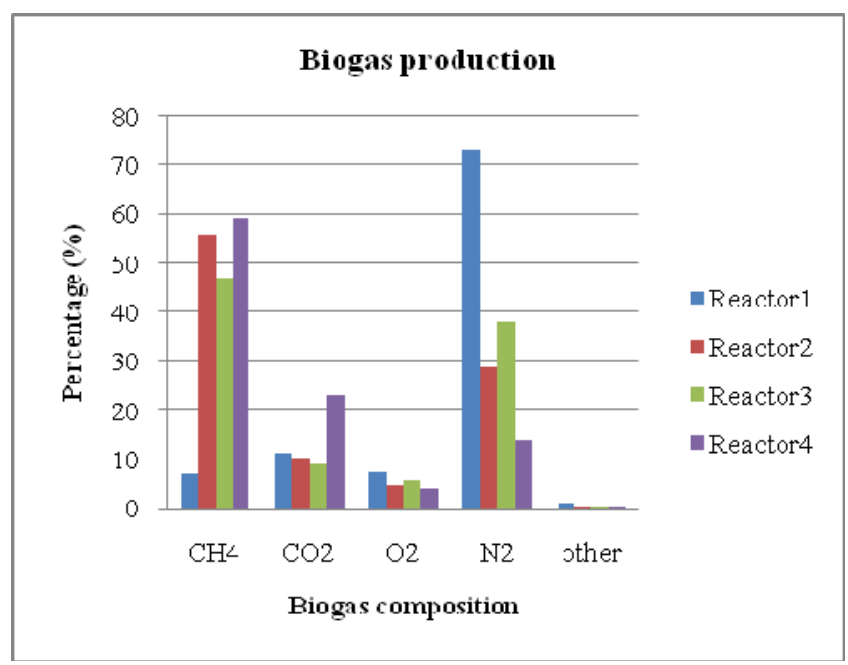

Fig. 5. Biogas composition from reactor

Fig. 5 shows the biogas production from anaerobic batch reactor experiment. Methane production from reactor 1 shows less than $10 \%$ were obtained. This may an error occurred due to leaking of air inside reactor. The reactor $2-3$ were 48 , and $55 \%$, respectively. The highest methane production $58 \%$ obtained from reactor 4 , these due to the addition food wastes were increased COD concentration and higher organic loading to the system, where closely to methane production under anaerobic condition 65\% [10] 60-70\%, 55-75\% [15] and 60-70 [4] The methane production may efficiency by complete mixed process where bacterial and organic matters were easily degraded [4] Moreover, 10 and $20 \%$ of nitrogen dioxide were obtained from this experiment. This may because under anaerobic condition, organic matters were mainly treated. However, sTKN was not treated under the process [14]. The others gas also appeared in this experiment and it may due to an error during measurement method.

4 conclusions

In this study, anaerobic batch reactor experiments were conducted to investigate the COD removal and methane production from night soil and night soil with additional 10\% food waste. The 4 batch reactors where reactor 1-3 night soil 
were contained as a fermentation materials and for reactor 4 the night soil and $10 \%$ food waste were investigated. The experiments were operated at room temperature varies from 25-37 ${ }^{\circ} \mathrm{C}$ and were experimented within 3 months. The results show that almost $90 \%$ COD removal for obtained from both night soil and night soil with $10 \%$ additional food waste experiment more than $50 \%$ methane production. Moreover, sTP and sTKN were also investigated in this experiments. The results show that sTP were increase slightly and sTKN remains constant in anaerobic treatment condition. From the experiment, results show the benefit of using anaerobic treatment in community wastewater by mixture of night soil and food waste for methane production as a renewable energy returning back to any places. The extend of continuous experiment is also interested and should have done for investigate methane production.

\section{ACKNOWLEDGEMENT}

This study was supported by Faculty of Engineer, Kasetsart University. The authors also would like to thank Dr. Peerakarn Banjerdkij for review and suggestion.

\section{REFERENCES}

[1] E. W. Rice, R. B. Baird, A. D. Eaton, and L. S. Clesceri. "Standard Methods For the Examination of Water and Wastewater ${ }^{\mathrm{TM}}$ " $22^{\text {nd }}$ ed. NW Washington: APHA, 2012.

[2] Analysis water quality handbook, $5^{\text {th }}$, San E.68 Co.,2008.

[3] H. R. Clark and R. E. Speece, "The pH Tolerance of Anaerobic Digestion," in Proceeding of the $5^{\text {th }}$ International Conference on Water Pollution Reserch, Nonthaburi, 1971.

[4] S. Sirianuntapiboon, Wastewater Treatment System: Selection, Design, Operation and Problem Solving, Bangkok, Top Publishing, 2006.

[5] S. Hirunmasuwan, Biological wastewater treatment and wastewater treatment design. BKK : Siamstationary supply, 2010.

[6] S. Siriwittayapakorn, Wastewater Technology, $2^{\text {nd }}$ ed. Bangkok: Department of Environmental Engineering, Faculty of Engineer, Kasetsart University, 2008.

[7] T. D. Reynolds, T. Richards, P. A., Unit operations and processes in environmental engineering. Inlternational Tomson Publishing, Inc., 1996.
[8] K. Funchigami, K. I. Mizuno, T. Minegishi, H. Atsuura, and S. Ishimoto, "Methane fermentation of night soil sludge and kitchen waste mixure," NKK Technical Review, no. 85, pp. 44-50, 2001

[9] S. Pranamaka, O.Tojumsri, "The simple wastewater treatment system for canteen,” M.S. thesis, Dept. Scince., Naresuan Univ, Pitsanuloak, Thailand.

[10] T. George, B. L. Franklin, and H. D. Stensel, Wastewater Engineering Treatment and reuse, $4^{\text {th }}$ ed. New York: McGraw-Hill, 2006.

[11] A. M. Omer and Y. Fadalla. "Biogas energy technology in Sudan," Renewable Energy, vol. 28, pp. 499-507, 2003.

[12] N. Chaitanoo and P. Aggarangsi, "Efficiency and Economic Analysis of Thermophilic CSTR Anaerobic Digester in Treating," Engng. $J$. $C M U$, vol. 16, no. 3, pp. 74-84, 2009.

[13] K. Udomsinrot, "Wastewater Engineer,"vol.4, $1^{\text {st }}$ ed.Bangkok,2000.

[14] K. P. Jha, "Recycling and reuse of human excreta from public toilets through biogas generation to improve sanitation, community health and environment," 2001, pp 1-6.

[15] I. V. Yentekakis, T. papadam, and G. Goula, "Electricity production from wastewater treatment," Solid State Ionics, vol. 179, pp 1521-1525, 2008 .

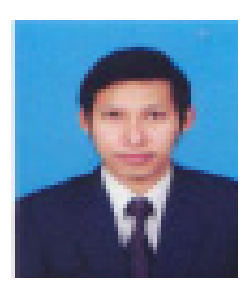

Assadawut Khanto was born at Bangkok, Thailand on 22 February 1984. After graduated B.Eng. in Civil Engineering, Mahidol University, Bangkok, Thailand in 2005. He continued his Master and obtained M.Sc. in Environmental Engineering at Aalborg University, Aalborg, Denmark in 2007.

$\mathrm{He}$ is now enrolled as a Ph.D student in Department of Engineering, Faculty of Engineer, Kasetsart University, Bangkok, Thailand. $\mathrm{Mr}$. Khanto is a membership of council of engineer, Thailand in both Civil and Environmental Engineer.

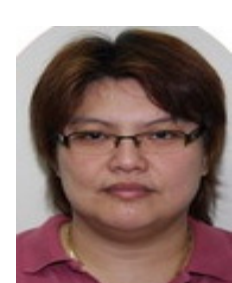

Peerakarn Banjerdkij was born at Bangkok, Thailand on 22 April 1970. After graduated B.Sc. in Rural Technology, Thammasat University, Bangkok, Thailand in 1992. She obtained her M.Eng. in Civil Engineering at Kasetsart University, Bangkok, Thailand in 1996. Afterward, she obtained D.Tech.Sc. in Toxicology Technology and Management, Asian Institute of Technology, Bangkok, Thailand, 2003.

She is working as a Lecture of Environmental Engineering Department, Faculty of Engineering at Kasetsart University, Bangkok, Thailand. 